\title{
Citizenship acquisition of Turkish immigrants in Canada and Germany: a comparative analysis
}

\author{
Deniz Yetkin Aker@
}

\begin{tabular}{l}
\hline Correspondence: denizyetkin8@ \\
gmail.com; dyaker@nku.edu.tr \\
Department of Political Science and \\
Public Administrations, Namık \\
Kemal University Faculty of \\
Economics and Administrative \\
Sciences, Namık Kemal Mah \\
Kampüs Cad. No.1, 59030 Tekirdağ, \\
Turkey
\end{tabular}

Correspondence: denizyetkin8@ gmail.com; dyaker@nku.edu.tr Public Administrations, Namık Kemal University Faculty of Economics and Administrative Turkey

\begin{abstract}
This study aims to shed light on how high-skilled and business Turkish immigrants (HSBTI) decide to acquire host country's citizenship and why some of them choose not to seek naturalization. With this in mind, a comparative case study of Canada and Germany was designed. It is proposed that host country citizenship and migration policy, social, economic and political costs and benefits of host country's citizenship and individuals' conceptualization of citizenship impact the decisionmaking process of HSBTI. Based on the data results, the study argues that social, economic and political opportunities in host countries (such as the right to vote), multicultural migration and citizenship policies of those countries and valuing citizenship as a commodity positively influence the naturalization decisions of HSBTI interviewees, while restricted policies, economic costs of citizenship and seeing citizenship as a sense of belonging adversely affect their decisions.
\end{abstract}

Keywords: Naturalization, Canada, Germany, Skilled migration, Turkish immigrants, Qualitative research

\section{Introduction}

Naturalization is the procedure of citizenship acquisition for several reasons, such as gaining political rights. Although some scholars posit that non-citizens have several rights just as citizens do (such as, Bloemraad, 2000; Soysal, 1996), Wallace-Goodman points out, for immigrants "naturalization is still the key to full rights of citizenship" (WallaceGoodman, 2010, p. 3). Despite all the rights and benefits associated with citizenship acquisition, not all immigrants (can or want to) obtain host country's citizenship. Especially since 1982, many studies dwell on the naturalization processes and policies to understand reasons of such variance in citizenship acquisition rates and dissimilarities in citizenship regulations among nations (Bloemraad, 2000, p. 13) (such as Bloemraad, 2002; De Voretz \& Pivnenko, 2005; Yang, 1994 and Vink \& Dronkers, 2012).

In the literature, variation in immigrants' naturalization rates is based on the following categories ${ }^{1}$ : the effect of socioeconomic environment (such as Yang, 1994) (Vink \& Dronkers, 2012, p. 5); individual's socioeconomic and cultural successes and demographic characteristics (Euwals, Dagevos, Gijsberts, \& Roodenburg, 2007, p. 4); the

\footnotetext{
${ }^{1}$ This categorization has similarities with the one of Vink and Dronkers (2012).
}

() The Author(s). 2019 Open Access This article is distributed under the terms of the Creative Commons Attribution 4.0 International License (http://creativecommons.org/licenses/by/4.0/), which permits unrestricted use, distribution, and reproduction in any medium, provided you give appropriate credit to the original author(s) and the source, provide a link to the Creative Commons license, and indicate if changes were made. 
effect of cultural similarities (see for instance Yang, 1994) (Vink \& Dronkers, 2012, p. 7); the effect of personal skills (such as language competence (Vink \& Dronkers, 2012, p. 8); and attitudes toward immigrants (ex. Bloemraad 2002).

More specifically, the objective of the study is to investigate high-skilled and business Turkish immigrants (HSBTI) who moved to Germany and Canada between 2000 and 2010. This is because there is an increasing competition for highskilled immigrants among countries such as Canada and Germany. Especially over the period 2000-2010, both Canada and Germany have introduced new immigration and citizenship policies considering the recent needs of the market, thereby increasing the number of high-skilled immigrants. Besides, the EU member states compete with countries such as the United States and Canada for high-skilled Turkish migrants (Köşer-Akçapar \& Yurdakul, 2009, p. 139).

Since the early 2000s, almost 4000 of Turkish university graduates and skilled workers have moved to countries such as Australia, Canada, the US, and European countries every year (İçduygu, Kaya, \& Tokuzlu, 2013). However, not all of the high-skilled and business Turkish immigrants decide to acquire host country's citizenship. For instance, there is a decrease in naturalization rates of Turkish nationals in Germany (Kaya, 2009, p. 49). With respect to high-skilled and business Turkish immigrants, this study put forwards the view that host country citizenship and migration policy (whether it is restricted or multicultural); economic, social and political benefits and costs of host country's citizenship; and individuals' conceptualization of citizenship (as a sense of belonging or commodity) influence their naturalization decisions. In this sense, a theoretical framework for citizenship acquisition and a brief review of Canadian and German citizenship and migration policies will be presented and examined. Subsequently, research design of the study and data analyzes will be detailed and critically discussed.

\section{A general framework for the naturalization decision-making process}

In the main literature on naturalization, there is a difference between the studies focusing on the European countries and the ones focusing on the US, Canada and Australia. Studies regarding the Europe address to naturalization from a legal perspective; while studies on Canada or the US (where "naturalization has been relatively easy for most immigrants") examine immigrants' naturalization decisions. (Bloemraad, 2000, p. 13, 14) Nevertheless, the variation in immigrants' citizenship acquisition rates is explained by policies in one's country of origin and the host countries; states' approaches to migration; socioeconomic environment; integration; cultural similarities and cultural success; personal skills; attitudes of countries toward immigrants; economic cost and benefits; as well as by demographic characteristics.

Concerning the issue of integration, Bevelander and Veenman (2006), for instance, question the effect of adaptation considering socioeconomic integration of Turks and Moroccans living in the Netherlands. They employ "Social Position and Use of Public Facilities by Migrants (SPVA) 2002" survey data by drawing only Turks and Moroccans from the data set. As a result of multivariate analyses, they underline that "naturalization of Turks and Moroccans in the Netherlands is not positively related to cultural integration nor to employment integration" (Bevelander \& Veenman, 2006, p. 327). In conclusion, they explain these findings in light of the Netherlands' citizenship policies (Bevelander \& Veenman, 2006, p. 327). 
In a similar vein, Ersanilli and Koopmans investigate socio-cultural integration levels of immigrants in France, Germany and the Netherlands. They measure socio-cultural integration "by host-country identification, proficiency and use of the host- country language, and interethnic social contacts" (Ersanilli \& Koopmans, 2010, p. 773). According to the survey results, naturalization is positively related to socio-cultural integration in France and Germany "that have traditionally required a certain degree of cultural assimilation from their new citizens" (Ersanilli \& Koopmans, 2010, p. 773).

While the previous authors discussed socio-cultural factors, for instance, Jones-Correra and Bloemraad focus mainly on migration policies and regulations: Both of them examine the effect of states' general attitude toward migration in line with migration policies and normative positions of Canada and the US. A quantitative research study conducted by Jones-Correra covers the data from 1965 to 1997 signifies that policies in country of origin affect immigrants' naturalization decisions. Thus, immigrants from countries recognizing dual citizenship generally have higher naturalization rates in the United States than those who are from countries not recognizing dual citizenship (Jones-Correra, 2001, p 997).

Different from Jones-Correra, Bloemraad concentrates on normative stances (whether interventionist or autonomous) of countries in relation to immigrant integration. She postulates that normative stances of states give rise to combined or divided institutional structures between governments, ethnic bodies, and individuals. She selects the case study of Portuguese immigrants living in Massachusetts and Ontario (higher citizenship level of Portuguese immigrants than in Boston) which she labels Canada's integration system as an interventionist and US's integration system as an autonomous one. She suggests that government bureaucrats and the federal policy in Toronto encourage citizenship "through symbolic support and instrumental aid to ethnic organizations and community leaders" (Bloemraad, 2002, p. 193). In contrast, communities in Boston need to organize and support their members without direct state provision, resulting in lower citizenship acquisition (Bloemraad, 2002, p. 193).

While Bloemraad and Jones-Correra focus on migration policies in general, Yang conducts a quantitative research study in the US and explains naturalization rates from socioeconomic and cultural perspectives (Vink \& Dronkers, 2012, pp. 5, 7). He touches upon immigrants' personalities and the social contexts in their country of origin and in the host countries (Vink \& Dronkers, 2012, pp. 394, 396). By analyzing the PUMS (Public Use Microdata Sample) data from the 1980 U.S. census, he states that "economic, political, social, cultural and geographical conditions in the country of origin, and immigrants' ethnic communities and urban concentration in the country of destination" (Yang, 1994, p. 449) involve in immigrants' naturalization decisions. He maintains that adaptation of immigrants to the new society and demographic characteristics have also major implications for predict the probability of immigrants with hostcountry citizenship (Yang, 1994, p. 449).

Similarly, İçduygu explains immigrants' reasons for naturalization from socioeconomic perspectives. According to his study conducted in 1987, 10\% of Turkish immigrants living in Melbourne received Australian citizenship for its advantages such as freedom of movement. Most Turkish immigrants remark that they and their children will have better job opportunities after acquiring Australian Citizenship and they can even receive "permanent positions in the public and government services" in Australia (İçduygu, 2005, p. 211). 
Similar to Yang, Vink and Dronkers' study indicates that immigrants' personalities play a central role in explaining differences in naturalization rates. Vink and Dronkers claim that encouraging citizenship policies conditionally affect the rates of citizenship acquisition. Some of these conditions can be described as the years of residence in host countries and economic structures of home countries. For instance, they show that policies have positive effects on the rates "especially among first-generation immigrants with more than 5 but fewer than 20 years of residence" (Vink \& Dronkers, 2012, p. 390). They also stress that the naturalization rates of immigrants "from poor, politically unstable, and non-EU countries" (Vink \& Dronkers, 2012, p. 390) are higher than immigrants from other countries. As a consequence, naturalization rates are not only affected by citizenship laws and regulations, but also by economic and cultural structures of host and origin countries and of individuals themselves (Vink \& Dronkers, 2012, p. 390). Likewise, Vink, Prokic-Breuer, and Dronkers emphasize that more accessible citizenship policies do not have much effect on immigrants from highly developed countries, particularly those with fewer years of residence but have a significant effect on immigrants from less developed countries (Vink, Prokic-Breuer, \& Dronkers, 2013, p. 1).

Scholars also attempt to understand whether opportunities in host countries and demographic characteristics of immigrants affect their naturalization decisions. To illustrate, De Voretz and Pivnenko use Public Use Microdata Files (PUMF) from the 1991, 1996, and 2001 Censuses of Canada and discuss the effect of economic costs and benefits of host country citizenship on naturalization rates (De Voretz \& Pivnenko, 2005, p. 435). They suggest that due to wider economic benefits of citizenship, immigrants prefer to become Canadian citizens (De Voretz \& Pivnenko, 2005, p. 435), and there is a positive relationship between a higher professional status and the rate of naturalization (De Voretz \& Pivnenko, 2005, p. 447).

Lastly, some scholars argue that demographic factors are among possible reasons for variation in immigrants' citizenship acquisition rates. For instance, Logan, Oh, and Darrah conduct a case study in the US whereby they discuss whether individual-level variables (such as gender, age, and marital status) have any impact on citizenship acquisition rates. They conclude that "age, years in the U.S., English speaking ability, and education" (Logan, Oh, \& Darrah, 2012: affect the probability of pursuing U.S. citizenship.

Similar to previous studies in the literature, the current study highlights that citizenship and migration policies influence immigrants' naturalization decisions. Specifically, the study includes high-skilled and business Turkish immigrants in Germany and Canada and attempts to explore in what ways citizenship and migration policies affect their decisions. It proposes that multicultural policies positively influence immigrants' decisions to naturalize; whereas restrictive citizenship policies have negative effects on their naturalization decisions.

In the same host country, not all of the immigrants choose to seek naturalization even if they are able to. This study proposes that such difference among immigrants of the same host country might arise because of the different approaches to the concept of citizenship. Therefore, the study can contend that high-skilled and business Turkish immigrants' conceptualization of citizenship affects their naturalization decisions.

In an attempt to discuss and analyze these propositions, the initial codes are determined considering existing explanations in the literature. The following section focuses 
on the 2000s and draws insights from the citizenship and immigration policies of Canada and Germany.

\section{Migration and citizenship acquisition in Canada and Germany}

Until the 1960s, Canada had controlled foreign skilled worker inflow. With the change of the Canadian economic growth, Canada has preferred immigration following with its new necessities and interests (Elrick, 2007, p. 1). In 1967, the points system was introduced in Canada as an immigration management policy. This system allows immigration officers to give points to a candidate under classifications "such as education, language abilities, and employment opportunities" (Elrick, 2007, p. 2). After several amendments, the Immigration Act of 1976 was introduced, which completely changes Canada's immigration policy. The most important outcome of this policy was that immigrants will not be classified in regard to their national or 'racial' origin anymore. Instead, they will be categorized as independent applicants and will be evaluated only according to their granted points (Ray, 2005).

Canada's new policy for immigration, the Immigration and Refugee Protection Act (IRPA), was legalized in 2001. It allows foreigners to obtain permanent residency under one of the following categories: "the economic class ${ }^{2}$ (i.e., skilled workers, business immigrants, and their immediate family members, that is high-skilled and business immigrants are allowed through this class), the family class (i.e., spouses, partners, children, parents, and grandparents of Canadian citizens or permanent residents who agree to sponsor them), and the protected persons/refugee class (i.e., government-sponsored refugees, privately sponsored refugees and other protected persons)" (Elrick, 2007, p. 2). To attract especially international students, further support is provided to temporary workers and international students.

About citizenship, according to the Canadian Citizenship Act, a person is a citizen if, for instance, "( $a$ ) the person was born in Canada after February 14, 1977; the person has been granted or acquired citizenship pursuant to section 5 or 11 and, in the case of a person who is fourteen years of age or over on the day that he is granted citizenship, he has taken the oath of citizenship." ${ }^{3}$ According to the Act, to become a Canadian citizen the candidates should, for instance, first determine their eligibility, such as being a Canadian resident for 3 years. Then, they should be prepared for the citizenship test, and take the test if they are between the ages of 18 and 54 (Government of Canada, Determine your Eligibility). ${ }^{4}$

Similar to Canada, Germany has introduced several immigration policy reforms for better migration management since 2000 (Hailbronner, 2012, p. 8). Foreigners who have valid passports are allowed to migrate and live in Germany. They should receive

\footnotetext{
${ }^{2}$ This is "a category of immigrants selected for their skills and ability to contribute to Canada's economy. Economic Class immigrants include skilled workers, provincial and territorial nominees, business immigrants, Quebec skilled workers and Canadian Experience Class members, and their spouses and dependants." Retrieved from: http://www.cic.gc.ca/english/helpcentre/glossary.asp, Accessed 29 May 2019

${ }^{3}$ Canada Citizenship Act (R.S.C., 1985, c. C-29), Retrieved 21 January 2014 from http://laws-lois.justice.gc.ca/ eng/acts/c-29/page-2.html\#h-3.

${ }^{4}$ For example, "applicants 55 years of age or older are not required to meet the knowledge of Canada..." For further details please see: Government of Canada. Canadian Citizenship/Grant. Retrieved August 9, 2019 https://www.canada.ca/en/immigration-refugees-citizenship/corporate/publications-manuals/operationalbulletins-manuals/canadian-citizenship/grant/applicants-55-years-older-applications-received-june-11-2015. html. Accessed 9 August 2019.
} 
visa, (temporary) residence permit or (permanent) settlement permit (Federal Ministry of the Interior, 2011, p. 121). With the National Act 2000, foreigners are allowed to receive German citizenship "after eight years of lawful residence (instead of the earlier 15 years)" (Süssmuth, 2009, p. 2). In addition to that, by fulfilling some requirements such as having sufficient incomes for sustaining oneself (being able to pay living expenses) or having health insurance coverage, Germany allows immigrants to get long-term residence permit (Federal Ministry of the Interior, 2011, p. 121).

As in the Canadian Case, the economic category in Germany includes international student migration and international education is seen as a profitable business. To attract international students, Germany made amendments in the immigration policy by charging "negligible fees to international students at any enrollment level" (Hawthorne, 2008, p. 14). Nevertheless, the immigration policy of Canada is more inclusive than the one of Germany. Canada's immigration policy has several characteristics such as welldefined selection principles. However, as different from Canada, in Germany, even though individuals apply to the same categories, they do not pass the same evaluation processes. For instance, EU citizens do not need to receive work permit unless they are citizens of Romania and Bulgaria. ${ }^{5}$ High- skilled candidates from non-EU countries, on the other hand, could receive residence permit for working in Germany only if it is essential by legal instruments or if there is an intergovernmental agreement between Germany and their home countries (Federal Ministry of the Interior, 2011, p. 121).

About citizenship, before January of 2000, German citizenship acquisition was not a rule but an exception. Accepting the jus soli principle was one of the most important innovations of the 2000 reform in the Nationality Law (Hailbronner, 2012, p. 15). With the new law, applicants do not need to have an ethnic bond but must fulfill several criteria such language criteria (either by going to a German school for a minimum of 4 years or a German language school to get a certificate) (Kaya, 2009, p. 45).

According to the amendment in 2000, children born in Germany belong to any nationality, and those whose parents (at least one of them) have residence permit at least for 8 years, are allowed to get German citizenship automatically. These children are also allowed to hold dual citizenship until adulthood, later they should decide which citizenship they want to hold until the age of 23. However, this means that although the new German citizenship law agrees to the concept of jus soli, this right would be invalid for those who do not want to renounce their country citizenship (Howard, 2005, p. 710-12). Thus, this recent change in 2000 may facilitate German citizenship acquisition and automatic naturalization by birth for the second and third generations (Faist, Gerdes, \& Rieple, 2004, p. 929), but German nationality legislation is still very restrictive especially due to its principle of preventing dual nationality (Faist et al., 2004, p. 926), such as to Turkish immigrants.

Because of the recent amendments and the difference in migration and citizenship approaches, this study focuses on Canada and Germany: Although global economic developments and new economic needs force Canada and Germany to reconsider their citizenship and immigration policies, German immigration and citizenship policy remains restrictive and exclusivist, especially for third-country nationals, whereas

${ }^{5}$ Arbeitsangetur. Retrieved from http://www.arbeitsagentur.de/nn_426134/EN/zentraler-Content/Arbeiten/ Arbeit-in-Deutschland-EN.html. 
Canada's immigration and citizenship policy is more inclusive and multicultural ${ }^{6}$ in terms of ensuring equal opportunities for candidates from every country. Further discussions, research design of the study and data results will be presented and critically analyzed in the following sections.

\section{Methodological note}

This study sample includes immigrants whose country of origin is Turkey, and who moved from larger Turkish cities between 2000 and 2010 as high-skilled and business immigrants to Canada and Germany with visa (for the Canadian case with permanent residency and for the German Case (generally) with temporary residency).

There are several reasons why this study revolves around high-skilled and business immigrants: The global integration of markets for goods, services, and capital requires an increase in the number of international immigrants. To promote free trade and investment, countries need to manage higher levels of migration. According to OECD statistics, in the current century, developed countries such as Canada prefer to attract high -skilled and business migrants (OECD, 2013, p. 34). Many countries (such as Canada and Germany) prefer to become guarantors for not all categories of migration but high-skilled migration. The reason is that those immigrants are not high in numbers and it would be less likely to have political resistance by their citizens toward highly skilled immigrants (Hollifield, 2004, p. 902).

Since skilled migration is related to economic class or economic migration, the present study uses Castles' categorization of high-skilled and business immigrants (Castles, 2000, p. 270) that incorporates "managers, executives, professionals, technicians or similar, who move within the internal labor markets of transnational corporations and international organizations or who seek employment through international labor markets for scarce skills" (Castles, 2000, p. 271) as well as international students (OECD, 2013, p. 34).

As previously discussed, Canada allows high -skilled individuals to migrate to the country through the "economic class" and it has continuously increased since 1999 (Statistics Canada, 2012). Most importantly, almost 60\% of all the immigrants who moved to Canada fall into this economic category (Challinor, 2011). Similarly, in the last century, migration - especially economic migration- to Germany has increased, mostly from other European Union countries. For instance, in 2011 the migration flow increased by $23 \%$ from the previous year (Federal Statistical Office of Germany, 2013, p. 20) and in 2008, almost half of the EU-residents migrated to Germany for employment-related reasons (OECD, 2013, p. 254). Besides, to improve the governance of international migration, states

${ }^{6}$ Multicultural policies and bilingualism were introduced as a solution against growing Québec nationalism and as a solution toward conflict between the French and English majority and other European immigrants who came to the country in the twentieth century. (Elrick, 2007. "Country Profile: Canada," Focus Migration (8). Retrieved from http://focus-migration.hwwi.de/Canada.1275.0.html?\&L=1. 
categorize immigrants as, for instance, temporary labor migrants and high-skilled and business immigrants (Castles, 2000, p. 270). ${ }^{7}$

The primary data source for this study is based on legal texts of Germany and Canada, as well as in-depth, semi-structured face-to-face interviews (snowball method, only a few of them were through email or Skype, interview questions are provided in Additional file 1) conducted in these countries. Interviews with community leaders were conducted and a series of activities organized by Turkish immigrants were attended (such as Anniversary celebrations of the March 18 Çanakkale Victory) to obtain general information about the Turkish community. The continuous collaboration was formed with some of the associations such as Turquebec (The Turkish Quebec Cultural and Friendship Association) and in Berlin such as Allmende. In total, 157 interviews were conducted in 6 months (in 2011); the data analysis consists of 48 interviews from Germany and 64 interviews from Canada, which fit the aim of the study (List of Case summaries are provided in Additional file 2).

\section{Reasons for citizenship acquisition: a comparative analysis Citizenship and migration policies}

As claimed by Vink and Dronkers (2012), encouraging citizenship policies have impact on citizenship acquisition rates: According to data results, it is seen that while restrictive citizenship and migration policies in Germany adversely affect the naturalization decisions of HSBTI (in the sense that they do not consider acquiring German citizenship, since dual citizenship is not allowed for Turkish citizens as third nationals), multicultural citizenship and migration policies in Canada have positive effects on naturalization decisions of HSBTI. However, unlike Vink, Dronkers and several other scholars, this study is not quantitatively concerned with the years of residence or other factors in relation to migration policy. It intends to figure out in what ways the policies affect HSBTI's naturalization decisions from a qualitative perspective.

With this aim in mind, it is observed that there are three crucial differences between the Canadian and German cases regarding the issue of migration and citizenship policy. These differences are valuing citizenship acquisition as a right, the issue of simplicity and the issue of dual citizenship. For instance, in Canada, after being Canadian residents for 3 years, candidates can make citizenship application and be prepared for the citizenship test (Government of Canada, Determine your Eligibility). HSBTI interviewees see this requirement as a right granted to immigrants: Unlike Germany, in Canada, many participants decide to pursue Canadian citizenship since they argue that it is their right to pursue one, or since citizenship application is a standard procedure for permanent residents (20 interviewees).

As an example, a female interviewee from Montreal $[\mathrm{A} 1]^{8}$ says, "It is my right to make citizenship application." A participant from Toronto [A45] states, "After living here, everything happens automatically. First, you become an immigrant, then a Canadian citizen." A male participant from Toronto [A51] specifies that individuals who migrated to Canada can stay in the country as long as they want to, and it

${ }^{7}$ For further examples of categorization and detailled discussions on the concept citizenship, please see, for instance, The Oxford Handbook of Citizenship, eds. Ayelet Shachar, Rainer Bauboeck, Irene Bloemraad, and Maarten Vink (2017).

${ }^{8}$ The numbers and the letters specify each interviewee. For details about the interviews, please check the list of case summaries. 
allows immigrants to acquire Canadian citizenship within 3 years. Similarly, a male participant from Toronto [A65] utters that since Canada allows immigrants to naturalize after 3 years, ${ }^{9}$ it is not reasonable to live as an immigrant in Canada for more than 5 years.

The second difference regarding the migration and citizenship policies of Canada and Germany is simplicity: The qualitative data analysis indicates that well-defined selection principles of Canada's immigration policy affect HSBTI interviewees' naturalization decisions positively, while complicated application and eligibility procedures of Germany affect the naturalization decisions of HSBTI interviewees negatively. A female interviewee from Berlin [B9] states, "You should work with a contract for at least five years and then you can obtain a German residence permit. Then, you follow a long procedure, or you marry a German. I am not planning to do anything for getting German citizenship." A male interviewee from Berlin [B42] replies as follows: "Until getting a residence permit, you should work for some time in a company and the company should say that 'We need this employee,' etc. I am not close to accomplishing any of these requirements, so I do not consider getting it (German citizenship)." On the other hand, for instance, a male participant from Toronto [A55] states that Canada has a very standard immigration procedure, which is efficient and clear.

The third difference is the issue of holding dual citizenship: In the literature, the decrease in naturalization rates of certain nationals in Germany is explained by the dual citizenship problem (Kaya, 2009, p. 49), and Jones-Correra (2001) argues that policies in a country of origin affects immigrants' naturalization decisions. Similarly, it is observed that, HSBTI interviewees emphasize the importance of dual citizenship opportunity given both by the home and host countries.

While Canada and Turkey allow Turkish citizens to hold dual citizenship, Germany does not allow many third nationals (such as Turkish citizens) to hold dual citizenship. As indicated in Fig. 1, in Germany, 46 interviewees hold Turkish citizenship and 2 of them have German citizenship. In the Canadian case, only 27 of the participants are Turkish citizens, 36 of them have dual citizenship (Canadian and Turkish), and one of them holds Canadian citizenship (no further information was available regarding the reason behind renouncing Turkish citizenship).

A female participant from Montreal [A9] says that since Turkey allows dual citizenship, becoming dual citizens (Turkish and Canadian) is very normal. A male interviewee from Toronto [A50] says, "The Turkish citizenship is very important for me; I cannot renounce it." A female interviewee from Toronto [A76] argues that since Canada and Turkey allow having dual citizenship, she decided to pursue Canadian citizenship with a clear conscience: "Otherwise, I would have not applied." A male interviewee from Toronto [A53] states ".... Of course, for us not having the obligation to renounce our citizenship was an advantage since both Canada and Turkey allow dual citizenship."

\footnotetext{
9"To become Canadian citizens, adults must have resided in Canada for at least 3 years (1095 days) in the past 4 years before applying. Children under the age of 18 do not need to meet this requirement. You may be able to count time you spent in Canada before you became a permanent resident if that time falls with the 4 years period." Government of Canada. Determine Your Eligibility. Retrieved 2 January 2014 from http://www. cic.gc.ca/english/citizenship/become-eligibility.asp.
} 


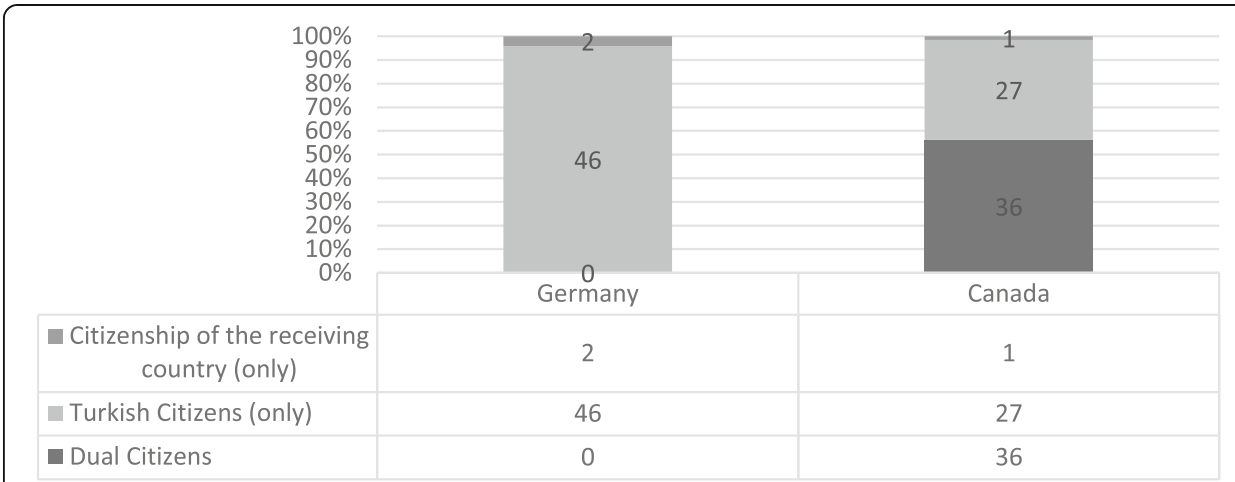

Fig. 1 Citizenship Rates in Canada and Germany. The figure is based on the relationship between interviewees living in Canada or Germany and their citizenship status. It demonstrates both the number and the percentage of interviewees holding dual citizenship, non-Turkish citizenship or Turkish citizenship. Source: The Figure is constructed by the author based on data collected in Canada and Germany

Although it is not the primary objective of the study, it is observed that host countries' citizenship and migration policies affect even the destination selections of HSBTI interviewees. ${ }^{10}$ Some of the HSBTI interviewees in Canada select the country as a destination after considering migration and citizenship policies of several other countries such as Australia. They believe that Canada has very easy citizenship requirements and has a more welcoming immigration policy with a very straightforward immigration procedure (efficient and clear), when compared to other countries. As a result, they choose Canada as their country of destination.

For instance, a female interviewee from Ottawa [A22] states, "I heard that coming to Canada is easier than other countries. So, I decided to come." Another female interviewee [A29] states, "I made a research (about immigration policies). For instance, Australian immigration policy seems unfriendly. I never considered America since its Green Card policy depends mostly on nothing more than luck. I never wanted to live in Germany. No option left but Canada." A male interviewee from Montreal [A4] says that since Canada is a multicultural state and he can live in Canada peacefully, he decided to migrate to Canada. Regarding "citizenship acquisition," he states that the fact that Canada offers a simple citizenship motivates him to choose Canada as a host country.

\section{Social, economic and political opportunities in host countries}

Yang's study (Yang, 1994) demonstrates that "economic, political, social, cultural and geographical conditions in the country of origin (449) generally affect immigrants' decision about naturalization." Similarly, the data result suggests that social, political and economic costs and benefits (sometimes as opportunities and sometimes as rights) of host countries' citizenship affect HSBTI interviewees' naturalization decision-making processes.

\footnotetext{
${ }^{10}$ It is observed that economic opportunities in host countries also affect the destination selections of HSBTI interviewees. Some HSBTI interviewees chose Germany as a destination country because of its easier application procedures for college education, affordable or no tuition fees, and scholarship options. For instance, a male interviewee from Berlin [B16] claims that since universities in Germany are free or cheaper than many other countries, he decided to come to Germany without making too much planning or research.
} 
When it comes to economic opportunities, as De Voretz and Pivnenko (2005) suggest, due to the large economic gains of citizenship, HSBTI interviewees in Canada prefer to be naturalized, while due to the economic costs of citizenship, HSBTI interviewees in Germany prefer not to be naturalized. In Canada, some of the interviewees state that becoming a Canadian citizen is important for its economic opportunities, such as finding a government job (similar to İçduygu's study (2005) in Australia) or lowering the expenses of education. A male interviewee from Ottawa [A31] states that since he wants to work for Canada's Federal Government in the future, he made a citizenship application. Another participant from Toronto [A56] prefers pursuing citizenship since it is helpful while searching for a government job. A female interviewee from Ottawa [A33] says, "I applied for Canadian citizenship for its benefits. First of all, I want to be a citizen to avoid paying higher tuition fees."

Due to high costs of acquiring German citizenship, such as loss of property rights, some of the HSBTI interviewees do not want to be naturalized: Germany does not allow dual citizenship for Turkish nationals, and if Turkish nationals want to acquire German citizenship then they should renounce their Turkish citizenship. Some interviewees, inaccurately, believe that renouncing Turkish citizenship cause them to become foreigners in Turkey and be subject to the Law on Foreigners and International Protection in Turkey, where have been some limitation on acquiring immovable property (has been abolished in 2012). A female interviewee [B25] states, "All of my inheritance from my family and my properties are in Turkey. I would not consider pursuing German citizenship."

In addition, thanks to several social and economic opportunities in Canada and Germany, some of the HSBTI interviewees decide to acquire those countries' citizenship. In Canadian Case, they state that naturalization is important in terms of retirement rights and the future of their children. According to an unemployed female participant from Canada [A5], it is very important to gain retirement rights after receiving Canadian citizenship. A married female student from Montreal [A18] believes that after receiving Canadian citizenship she has secured the future of her children. According to her, her children can live in Canada, work there, and will not have a hard time in Canada since they were grown up there.

It is also observed that HSBTI interviewees in Canada and Germany want to be naturalized to guarantee their social or political life: Some interviewees, (such as A20 (a male interviewee from Montreal) and A36 (a male interviewee from Ottawa)), explain that unlike Canada, political, economic, and social conditions in Turkey are not stable. They believe that if anything bad happens in Turkey, they can live in Canada. A male from Canada [A17] explains that being a Canadian citizen is a guarantee and he will be secure from political turmoil in Turkey. Some interviewees, [such as A20 and A36] think that the Turkish political conditions are unstable and prefer to get Canadian citizenship to guarantee their future.

Given that Germany will probably stay as a stable country, some HSBTI interviewees in Germany remark that if anything bad happens in Turkey they can live in Germany. For instance, although a female interviewee [B8] does not want to pursue German citizenship, she stresses that she might consider pursuing it if someday she would not be free in Turkey anymore. She states "if one day, my country disregards my rights, if I can't support my ideas- Inshallah (God willing) -, then I will consider getting German 
citizenship for expressing my ideas, my academical works. It would be better for me to live in Germany and be a German citizen."

Regarding political opportunity, it is observed that since HSBTI interviewees want to be politically active in Germany and Canada; they want to be naturalized. A male interviewee from Ottawa [A27] states that citizenship will give him the right to vote and to be elected. A male interviewee [A61] explains his motive by saying, "I believe that voting is very important for being a citizen. This is a right." He says that he wants to contribute to governance. Similarly, a male respondent from Germany [B21] says that since he studies political science and he wants to become politically active in Germany, he considers pursuing German citizenship. A male from Berlin [B38] states, "As you know, German citizenship has some advantages. You can have the right to speak; I mean the right to vote, the right to stay in Germany, and visa exemption. Therefore, I want to get German citizenship."

As a political benefit, different from the German Case, some of the HSBTI interviewees from Canada want to be naturalized against discrimination and Islamophobia in the global world. This could be because interviewees believe that they will be discriminated in Germany. For instance, a male interviewee from Berlin [B39] states "Now in Germany, being a German citizen is only on paper. I mean, I have never been in America, but given the impressions I get from the Hollywood movies or the experiences of my friends, I can say that in America they (Turkish Immigrants $)^{11}$ have their Turkish identity with an American identity ... Generally in Germany, people of Turkish, Arab, Middle East origin are actually seen as foreigners even if they become German citizens."

In contrast to the German case, interviewees in Canada do not generally point out the problem of discrimination and they believe that Canadian Passport will be helpful against discrimination and Islamophobia in the global world. A male from Toronto [A57] explains the situation of islamophobia and discrimination when he says, "After September 11, our travels with Turkish passports began to be a problem. Maybe this is due to lack of [positive] publicity [for Turkey]." A male interviewee from Ottawa [A31] decides to pursue Canadian citizenship since Canada has a dignity in the world. A female interviewee [A57] states that she decided to pursue Canadian passport since it is considered as prestigious and it is respected by every country. A male interviewee from Montreal [A2] emphasizes "being a citizen of Canada is very advantageous since Turkey's image is apparent."

\section{The conceptualization of citizenship}

Different from the literature, this study argues that the meaning of citizenship for HSBTI interviewees in Germany and Canada affect their naturalization decisions. Thus, conceptualization of citizenship as a commodity has positive effects on immigrants' naturalization decisions, while conceptualization of citizenship as a sense of belonging negatively affects their decisions (especially in Germany where they cannot hold dual citizenship).

In the literature, Balta and Altan Olcay (2014) argue that only "transnational citizenship is physically transformed into a good, becoming part of the workings of the layers

\footnotetext{
${ }^{11}$ Explanations in parentheses are provided by the author.
} 
of economic transactions" (p. 140). In the same vein, Isin and Wood share their opinions suggesting that consumerism is a new kind of participation. From their point of view, there can be a movement toward consumer citizenship (Işıı \& Wood, 1999, p. 158). On the contrary, as seen in the present study, some interviewees do not consider a single concept of "citizenship": Some of them distinguish citizenship by birth from citizenship through naturalization. Thus, some HSBTI interviewees conceptualize "citizenship" as a commodity, while some of them conceptualize "citizenship through naturalization" as a commodity. For instance, a female from Ottawa [A33] expresses that she wants to become a Canadian citizen because of its opportunities and facilities. She says, "I know there is a difference between citizenship by birth and citizenship through naturalization."

Citizenship as a commodity HSBTI interviewees mostly decide to pursue the Canadian and German citizenships, if they see the concept citizenship as a commodity in the market, which "can be traded, bought or sold." 12 In this case, it can be bought (with money) or traded (after working in a host country getting citizenship in exchange (as barter)), and it can be used for satisfying several needs such as freedom of mobility for a new life, for finding jobs or for having education in various countries. As shown in Fig. 2, the most frequently mentioned reasons for pursuing Canadian citizenship include valuing Canadian citizenship as a commodity (28 interviewees) and viewing it as a way to gain freedom of mobility (freedom of mobility (13 interviewees) and visa problems (22 interviewees) which is 35 interviewees, in total).

Similarly, some interviewees in Germany decide to be naturalized since they see the German citizenship as commodity (14 interviewees) and since they want to move to other countries freely (freedom of mobility (7 interviewees) and visa problems (6 interviewees) which is 13 interviewees, in total) (Fig. 3).

Regarding the issue of commodity, for instance, an interviewee from Toronto [A50] states, "The only advantage of Canadian citizenship is the Canadian passport." Regarding the issue of the commodity as barter or as something that can be bought, one of the female participants from Toronto [A40] sees Canadian citizenship as a right in return for her moral support and material contribution by her family as immigrants to Canada. A male interviewee from Toronto [A53] tries to explain the situation in detail: "When you have arrived as a migrant, you should sacrifice certain things. I live here with lower standards then I had in Turkey. We asked ourselves what we could gain in return for those sacrifices. Since we do not have children, we could not benefit from educational advantages. Becoming citizens and getting a Canadian passport can be the only advantage for us, even though we will return to our homeland."

Similarly, a male interviewee from Berlin [B18] stresses that he can buy any country's citizenship with his money: "A State is a company and its citizenship is in the commercial system. For me, a state is a place where I pay my taxes as a citizen. I work, paid for my work, use the highway or metro to work, and use electricity. This is what citizenship means to me. I chose this state (Germany), today. The portfolio of Germany fits

\footnotetext{
${ }^{12}$ Cambridge Dictionary. Commodity. Retrieved from https://dictionary.cambridge.org/tr/sözlük/ingilizce/ commodity.
} 


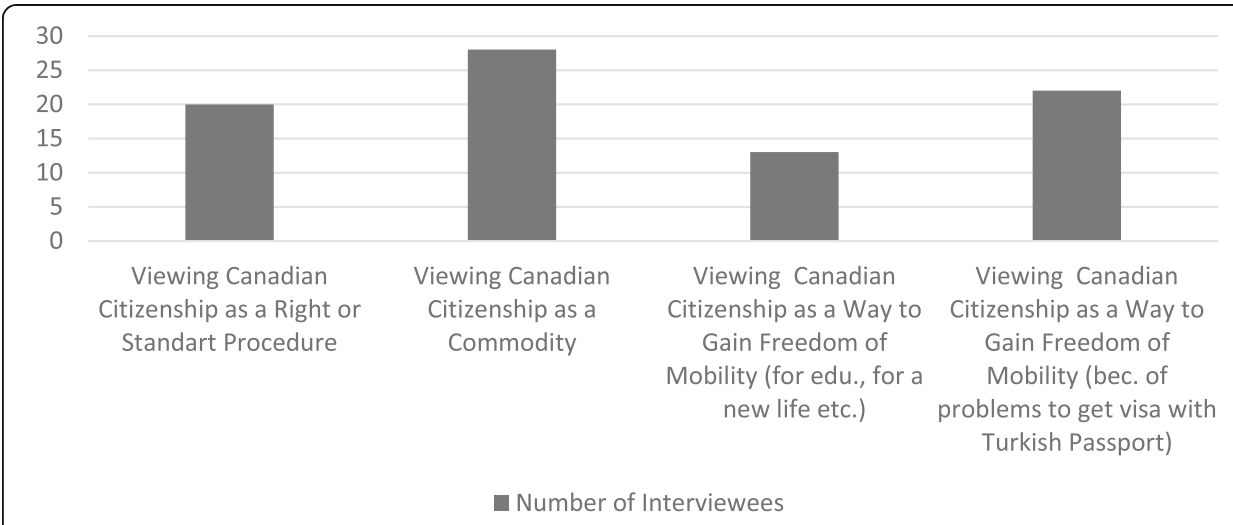

Fig. 2 Most Frequently Mentioned Reasons for Pursuing Canadian Citizenship. The graph provides the first three reasons that the participants stress out regarding the question of how they decided to pursue Canadian Citizenship. It does not give details about the number of participants but shows the most frequently mentioned reasons ( 6 or more) since participants can state more than one reason. Source: The Figure is constructed by the author based on data collected in Canada and Germany.

for me; therefore, I chose Germany. I have opportunities in Germany and pay for it. I can buy any country with my money."

In the literature, according to İcduygu (2005), only 10\% of the Turkish immigrants living in Melbourne were naturalized in Australia for its advantages such as freedom of movement. However, as different from the literature, this study suggests that many HSBTI interviewees conceptualize citizenship as a commodity that can be used for satisfying several needs such as freedom of mobility, and this conceptualization affects their naturalization decision making processes. For instance, given citizenship as a tool for satisfying needs, many HSBTI interviewees argue that Canadian and German passports provide great advantages in terms of living in those countries or freedom of movement. To illustrate a male interviewee from Montreal [A11] comments as follows "citizenship does not mean anything to me. I mean, it is very useful for life in Canada. For this reason, getting a Canadian passport will be advantageous for me." A female from Montreal [A1] remarks that "I considered becoming a dual citizen. I think it will

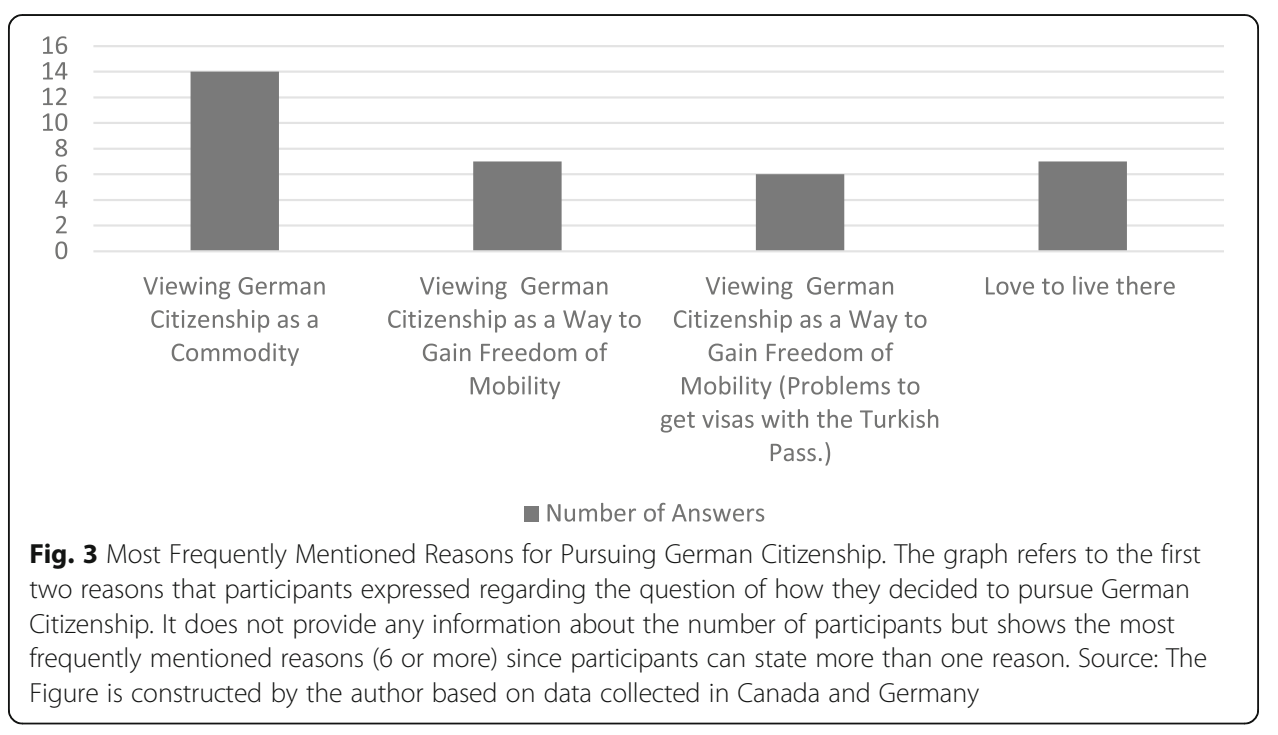


be very advantageous. I cannot say 'I am Canadian.' Adopting a place after the age of 20 is not an easy thing to do. I think that dual citizenship will benefit only for traveling; it cannot bring any disadvantage." Another female interviewee [A47] exemplifies the issue as follows: "I applied for a passport. If I had believed that I could travel around the world with a Turkish Passport, I would have considered filling out a Canadian citizenship application." A male from Montreal [A4] says that after he receives his Canadian citizenship, he will not feel like a Canadian. He thinks that it is a profitable tool. It will only bring several rights and provide opportunities as an "artificial bond."

Similarly, some of the interviewees in Germany decide to be naturalized since they see German citizenship as a commodity for satisfying their needs (15 interviewees) and since they want to move to other countries (for instance, to other European countries) to work or to travel freely (10 interviewees). ${ }^{13}$ Some of the HSBTI interviewees desire to travel all around the world and want to live or work in other countries than Germany. A respondent [B2] from Germany mentions that citizenship means benefiting from opportunities in a country. A female from Berlin [B17] says: "First of all, I want to acquire it (German citizenship) for freedom of movement. The doors are open when you are an EU citizenship. You can always be a part of collaborations in the European Union as an academician. I mean, with Turkish citizenship, we face several visa problems when we want to go to a European country for travel, a conference, or academic joint work."

With respect to the "satisfying needs," some of the interviewees in Germany believe that acquiring German citizenship is not advantageous; consequently, they do not want to pursue German citizenship. For instance, a male interviewee [B58] explains that Turkish immigrants can use their residence permits to travel around Europe and they do not need German citizenship for visa exemption.

Citizenship as a sense of belonging With respect to the issue of sense of belonging and the issue of commodity, one of the reasons why some of the HSBTI interviewees choose not to seek naturalization in Canada or Germany is their sense of belonging to Turkey. Two out of 78 interviewees from Canada say that they do not want to receive Canadian citizenship while 21 interviewees from Germany state that they did not apply for German citizenship. Although Canada allows dual citizenship, the reason why two interviewees in Canada decided against naturalization was their strong sense of belonging to Turkey. ${ }^{14}$

In spite of its possible benefits such as freedom of movement, some of the HSBTI interviewees in Germany conceptualize citizenship as a sense of belonging and do not want to renounce their Turkish citizenship. For instance, an interviewee [B8] claims that she is afraid of losing her identity and says, "At abroad, one misses his or her country a lot. At Turkish airport, I cannot line up in the non-Turkish Citizens Passport Control Desks. This upsets me a lot.” A female from Berlin [B6] underlines the sense of

\footnotetext{
${ }^{13}$ For instance, although interviewees prefer Canada since it is closer to the USA or since they want to receive Canadian citizenship for the sake of mobility, only two interviewees have plans to live in another country in the immediate future.

${ }^{14}$ Face to face interviews allow researchers to get both verbal and non-verbal clues. The author did not capture any non-verbal clue showing other (such as feeling guilty about leaving Turkey) reasons than sense of belonging.
} 
belonging to Turkey stating that, "First, I don't belong here (Germany). I am not German as they describe German citizenship and ethnic citizenship. I belong to Turkey and I will still feel that way if somebody tries to take away my identity from me."

\section{Conclusions}

In the literature, naturalization decisions of immigrants are explained by several issues, such as the effect of citizenship laws (both in the country of origin and destination); the effect of a socioeconomic environment; and the effect of cultural similarities. As proposed by this study, the data analysis reveals that host countries' citizenship and migration policies affect naturalization decision of HSBTI interviewees in Canada and Germany: The restrictive citizenship and migration policies in Germany adversely affect naturalization decisions of HSBTI and; the multicultural citizenship and migration policies in Canada positively influence naturalization decisions of HSBTI. As a result of an in-depth analysis, it is observed that such migration and citizenship policy differences between Canada and Germany impact on HSBTI interviewees' citizenship acquisition decisions in three ways: In Canadian case, well-defined selection principles, the criteria of being a permanent resident for 3 years and having no restrictions on holding dual citizenship are significant factors that positively affect HSBTI interviewees' decisions. As for German case, complicated application and eligibility procedures and restrictions on holding dual citizenship are major factors that influence HSBTI interviewees' decisions negatively.

Another important finding is that social, economic and political opportunities (and costs) in host countries shape naturalization decisions of HSBTI. Concerning economic opportunities, HSBTI interviewees in Canada prefer to be naturalized for finding permanent positions in the government and lowering educational costs. Different from Canadian Case, due to economic costs of citizenship, HSBTI interviewees in Germany prefer not to get naturalized as a German citizen. The economic costs are closely related to German restrictive migration and citizenship policy: Germany does not allow Turkish citizens to hold dual citizenship and those who renounce their Turkish citizenship have to waive all their rights of inheritance. For this reason, some of the HSBTI interviewees in Germany do not want to acquire German citizenship.

Regarding social opportunities, some of the HSBTI interviewees see German and Canadian citizenship as guarantee for their social life (i.e. freedom etc.), and for this reason, they want to apply for naturalization. In Canadian Case, some of the HSBTI interviewees decide to be naturalized to obtain retirement rights and ensure their children's future in Canada.

Regarding political opportunities, some of the HSBTI interviewees want to be naturalized for being secure and for political participation (ex. voting) in Canada and Germany. Different from the German case, some of the HSBTI interviewees want to acquire Canadian Citizenship against discrimination and Islamophobia around the world.

Finally, it is observed that the meaning of citizenship for HSBTI (whether they conceptualize citizenship as a commodity (and) or identity) affect their naturalization decisions in Canada and Germany: Conceptualizing citizenship (or citizenship through naturalization) as a commodity affect their decision positively, while conceptualizing citizenship (or citizenship by birth) as a sense of belonging adversely affect their decisions (especially in Germany where they should renounce Turkish citizenship). 


\section{Additional files}

Additional file 1: Interview questions (Translated into English). (DOCX $22 \mathrm{~kb}$ )

Additional file 2: List of the case summaries. (DOCX $59 \mathrm{~kb}$ )

\section{Abbreviations}

DAAD: German Academic Exchange Service; HSBTI: High-Skilled and Business Turkish Immigrants; PUMF: Public Use Microdata Files; TÜBITAK: Technological Research Council of Turkey

\section{Acknowledgments}

The author would like to thank anonymous reviewers for their valuable comments and suggestions. She would like to thank interviewees for their participation to the study and to thank Associate Prof. Dr. Saime Özçürümez for her support and guidance as the dissertation supervisor. (Saime Özçürümez, Bilkent University Political Science and Public Admins., 06800 Bilkent/Ankara/Turkey, saime@bilkent.edu.tr).

\section{Authors' contributions}

Deniz Yetkin Aker collects the data and prepares the whole manuscript. The author read and approved the final manuscript.

\section{Funding}

German Academic Exchange Service [DAAD] and the Scientific and Technological Research Council of Turkey

[TÜBITAK] support Deniz Yetkin Aker with scholarship for the field researches of this study in Canada and Germany.

\section{Availability of data and materials}

The manuscript includes qualitative data (face to face interviews, recorded) collected for a Ph.D. thesis by the author herself. This dataset analyzed during the current study is not publicly available due to the individual privacy of interviewees. The author has shared a list of case summaries for the details of the interview.

\section{Competing interests}

The author declares that she has no competing interests.

Received: 26 December 2018 Accepted: 21 August 2019

Published online: 28 October 2019

\section{References}

Balta, E., \& Altan Olcay, Ö. (2014). Market Embedded Transnationalism of Turkish Elites: Contemporary Turkey at a Glance. In K. Kamp, A. Kaya, F. Keyman, \& Ö. O. Beşgül (Eds.), Interdisciplinary Perspectives on Local and Translocal Dynamics. Wiesbaden: Verlag fuer Sozialwissenschaften.

Bevelander, P., \& Veenman, J. (2006). Naturalization and employment integration of Turkish and Moroccan immigrants in the Netherlands. Journal of International Migration and Integration, 7(3), 327-349.

Bloemraad, I. (2000). Citizenship and immigration: A current review. Journal of International Migration and Integration, 1(1), 937. https://doi.org/10.1007/s12134-000-1006-4.

Bloemraad, I. (2002). The North American Naturalization Gap: An Institutional Approach to Citizenship Acquisition in the United States and Canada. International Migration Review, 36(1), 193-228.

Castles, S. (2000). International migration at the beginning of the twenty-first century: global trends and issues. International Social Science Journal, 52(165), 269-281.

Challinor, A. E. (2011). Canada's immigration policy: A focus on human capital. Migration Policy Institute. Retrieved from http:// www.migrationinformation.org/Profiles/display..fm?lD=853. Accessed 6 Jan 2014.

De Voretz, D., \& Pivnenko, S. (2005). The economic causes and consequences of Canadian citizenship. Journal of Immigration and Integration, 6(3-4), 435-468.

Elrick, J. (2007). Country profile: Canada. Focus Migration, (8). Retrieved from http://focus-migration.hwwi.de/Canada.1275.0. html?\&L=1. Accessed 12 Dec 2018.

Ersanilli, E., \& Koopmans, R. (2010). Rewarding integration? Citizenship regulations and the socio-cultural integration of immigrants in the Netherlands, France and Germany. Journal of Ethnic and Migration Studies, 36(5), 773-791.

Euwals, R., Dagevos, J., Gijsberts, M., \& Roodenburg, H. (2007). The Labour Market Position of Turkish Immigrants in Germany and the Netherlands: Reason for Migration, Naturalisation and Language Proficiency (IZA Discussion Paper No. 2683). Retrieved from https:/www.iza.org/de/publications/dp/2683/the-labourmarket-position-of-turkish-immigrants-ingermany-and-the-netherlands-reason-for-migration-naturalisation-and-language-proficiency.

Faist, T., Gerdes, J., \& Rieple, B. (2004). Dual citizenship as a path-dependent process. International Migration Review 38(3), 913-944.

Federal Ministry of the Interior (2011). Migration and Integration: Residence Law and Policy on Migration and Integration in Germany. Retrieved 2 January 2014 http://www.bmi.bund.de/SharedDocs/Downloads/EN/Broschueren/Migration_und_ Integration_en.ht\%20ml?nn=2232296.

Federal Statistical Office of Germany. (2013). Year book 2012: Extract of Statistical Yearbook, (English version of the chapter as "Population, families, living arrangements"). Retrieved from https:/www.destatis.de/EN/Publications/Specialized/ Population/StatYearbook_Chapter2_5011001129004.pdf?_blob=publicationFile.

Hailbronner, K. (2012). Country Report: Germany. Florence: Robert Schuman Centre for Advanced Studies EUDO (European Union Observatory on Democracy) Citizenship Observatory, European University Institute. Retrieved from http://eudocitizenship.eu/docs/CountryReports/Germany.pdf. 
Hawthorne, L. (2008). The growing global demand for students as Skilled Migrants. Migration Policy Institute. Retrieved 1 May 2014 from http://www.migrationpolicy.org/research/growing-global-demand-students-skilled-migrants-0.

Hollifield, J. F. (2004). The emerging migration state. International Migration Review, 38(3), 885-912.

Howard, M. M. (2005). Variation in dual citizenship policies in the countries of the EU. International Migration Review, 39(3), 697-720.

Içcluygu, A. (2005). The international migration and citizenship debate in Turkey: The Individual Level of Analysis. In F. Keyman, \& A. liçduygu (Eds.), Citizenship in a Global World: European Questions and Turkish Experiences, (pp. 196-216). London: Routledge.

İçduygu, A., Kaya, I., \& Tokuzlu, L.B. (2013). Turkey. In P. Fargues (Ed.), EU Neighborhood Migration Report. European University Institute. Retrieved from http://issuu.com/eui-publications/docs/mpc_eu_neighbourhood_migration_repo?mode= embed\&layout=http\%3A\%2F\%2Fskin.issuu.com\%2Fv\%2Flight\%2Flayout.xml\&showFlipBtn=true.

Işın, E., \& Wood, P. K. (1999). Citizenship and identity. London: Sage Publications.

Jones-Correra, M. (2001). Under Two Flags: Dual Nationality in Latin America and its Consequences for Naturalization in the United States. International Migration Review, 35(4), 997-1029.

Kaya, A. (2009). Islam, Migration and Integration: The Age of Securitization. New York: Palgrave Macmillan.

Köşer-Akçapar, Ş., \& Yurdakul, G. (2009). Introduction: Turkish Identity Formation and Political Mobilization in Western Europe and North America. Turkish Studies, 10(2), 139-147.

Logan, J. R., Oh, S., \& Darrah, J. (2012). The Political and Community Context of Immigrant Naturalization in the United States. Journal of Ethnic and Migration Studies, 38(4), 535-554.

OECD (2013). International Migration Outlook 2013. Paris. OECD Publishing. https://doi.org/10.1787/migr_outlook-2013-en.

Ray, B. (2005). Canada: Policy Changes and Integration Challenges in an Increasingly Diverse Society. Migration Policy Institute Retrieved from http://www.migrationpolicy.org/article/canada-policy-changes-and-integration-challenges-increasinglydiverse-society/.

Soysal, Y. N. (1996). Changing Citizenship in Europe: Remarks on Post-National membership and the National State. In D. Cesarani, \& M. Fulbrook (Eds.), Citizenship, Nationality and Migration in Europe. London: Routledge.

Statistics Canada. (2012). Ethnic Diversity and Immigration. Retrieved from https://www150.statcan.gc.ca/n1/pub/11-402-x/2012 000/chap/imm/imm-eng.htm.

Süssmuth, R. (2009). The Future of Migration and Integration Policy in Germany. Migration Policy Institute. Retrieved from http://www.migrationpolicy.org/research/future-migration-and-integrationpolicy-germany.

Vink, M. P., \& Dronkers, J. (2012). Explaining Access to Citizenship in Europe: How Citizenship Policies affect Naturalization Rates. European Union Politics, 13(3), 390-412.

Vink, M. P., Prokic-Breuer, T., \& Dronkers, J. (2013). Immigrant Naturalization in the Context of Institutional Diversity: Policy Matters, but to Whom? International Migration, 51(5), 1-20.

Wallace-Goodman, S. (2010). Naturalization Policies in Europe: Exploring Patterns of Inclusion and Exclusion (EUDO Citizenship Observatory Comparative Report, RSCAS/EUDO-CIT-Comp. 2010/7). Italy: Badia Fiesolana, San Domenico di Fiesole (FI).

Yang, P. Q. (1994). Explaining Immigrant Naturalization. International Migration Review, 28(3), 449-477.

\section{Publisher's Note}

Springer Nature remains neutral with regard to jurisdictional claims in published maps and institutional affiliations.

\section{Submit your manuscript to a SpringerOpen ${ }^{\circ}$ journal and benefit from:}

- Convenient online submission

- Rigorous peer review

- Open access: articles freely available online

High visibility within the field

- Retaining the copyright to your article

Submit your next manuscript at $\boldsymbol{\nabla}$ springeropen.com 